\title{
DIGITAL LITERATION PROFICIENCY OF ELEMENTARY SCHOOL STUDENTS IN THE ERA OF THE INDUSTRIAL REVOLUTION 4.0
}

\author{
Dede Hadiansyah $^{1}$, Wawan Setiawardani², Muhammad Sholeh ${ }^{3}$ \\ ${ }^{1}$ STKIP Nahdlatul Ulama Indramayu \\ ${ }^{2}$ STKIP Nahdlatul Ulama Indramayu \\ ${ }^{3}$ STKIP Nahdlatul Ulama Indramayu \\ ${ }^{1}$ dedehadiansah9@gmail.com, ${ }^{2}$ wawansetiawardani@ stkipnu.ac.id, ${ }^{3}$ \\ sholehmuhammad23@yahoo.co.id
}

\begin{abstract}
Students at the age of primary education are faced with a challenge in using digital technology, namely (a) the ability to sort information that is suitable for use and follow; (b) addiction to digital technology and the internet; and (c) changes in behavior and character. The purpose of this study is to identify: (a) obtaining information from digital media by elementary school students; (b) the use of information from digital media by elementary school students using; (c) the challenges faced by elementary school students in obtaining information using digital media; (d) the expectations of elementary school students regarding learning using digital media. The research method used is the phenomenological research method. The results of the research, some students use digital literacy only to find information. Meanwhile, a few elementary students have carried out the learning process in the form of products from the use of digital literacy. Digital literacy can be a suitable learning medium in the era of the industrial revolution 4.0, but its use must be monitored and limited.
\end{abstract}

Keywords: Education, Industry 4.0, Digital Media.

\begin{abstract}
Abstrak
Siswa pada usia pendidikan dasar dihadapkan pada tantangan dalam menggunakan teknologi digital, yaitu (a) kemampuan memilah informasi yang sesuai untuk digunakan dan diikuti; (b) kecanduan teknologi digital dan internet; dan (c) perubahan perilaku dan karakter. Tujuan dari penelitian ini adalah untuk mengidentifikasi: (a) memperoleh informasi dari media digital oleh siswa sekolah dasar; (b) pemanfaatan informasi dari media digital oleh siswa sekolah dasar; (c) tantangan yang dihadapi siswa sekolah dasar dalam memperoleh informasi dengan menggunakan media digital; (d) harapan siswa sekolah dasar tentang pembelajaran dengan menggunakan media digital. Metode penelitian yang digunakan adalah metode penelitian fenomenologi. Hasil penelitian, beberapa siswa menggunakan literasi digital hanya untuk mencari informasi. Sementara itu, sebagian kecil siswa SD telah melaksanakan proses pembelajaran berupa produk dari pemanfaatan literasi digital. Literasi digital bisa menjadi media pembelajaran yang cocok di era revolusi industri 4.0, namun penggunaannya harus dimonitor dan dibatasi.
\end{abstract}

Kata Kunci: Pendidikan, Industri 4.0, Media Digital.

\section{INTRODUCTION}

The industrial revolution 4.0 is known as the era of digitalization in different life (Suwardana, 2017: 103), including in the education sector. The effects that occur include literacy skills. Literacy skills in the era of industrial revolution 4.0 emphasize reading, writing, and numeracy skills and emphasize the importance of digital literacy skills, technological literacy, and human literacy (Suwardana, 2017: 107; Yahya, 2018: 13-14). Digital literacy is the ability to read, analyze, and use digital information. Technological literacy is concerned 
with increasing expertise in machines and technological applications. Human literacy is the ability to communicate and socialize well.

The industrial revolution is a change in which the production of goods has added commercial value in nature with the efficiency of time and labor. Suwardana (2017: 13). We are currently entering the era of the industrial revolution 4.0, an era in which the digital industry has become a paradigm and reference in today's life system. The age of the industrial revolution 4.0 coincided with the period of disruption. To face the industrial revolution 4.0 or the era of disruption, "new literacy" is needed in addition to old literacy. Old literacy today is used as capital to take part in people's lives (Fitriyani.Y \& Aziz.A.I, 2019: 100).

Firman explained that one way to improve the quality of education through information technology is by organizing digital literacy in schools. Digital literacy can understand and operate digital technology optimally (Herlina et al., 2019: 2).

In Indonesia's context, the flow of technological development must be translated by changing learning systems and patterns in schools. Indah Kurniasih explained that the advancement of information technology and the internet today has resulted in various and abundant digital-based information narratives (Anggraeni.H, et al., 2019: 191) so that digital learning is a must and cannot be avoided. Therefore, learning activities that are still dominated by conventional models, textual using books/books as the main reference must be implemented by making maximum use of digital media (digital-age literacy).

The 4.0 industrial revolution also presents opportunities and challenges for education, including challenges for students who have not been able to appropriately use the information and digital technology. Therefore, a study of students' digital literacy skills is needed to understand how they use digital technology and process digital information and what challenges they face in processing this information. This research is entitled "Digital Literacies Skills for Elementary School Students in the Industrial Revolution Era 4.0".

Besides, this study seeks to holistically understand how students' literacy skills are one of the six basic literacy skills expressed in World Economic Forum 2015. This research is also expected to make challenges for education in the digital era to improve the quality of education.

\section{METHOD}

The method used in this research is a phenomenological study. Phenomenological studies seek answers to the meaning of a phenomenon. Phenomenological research describes several individuals' general meaning to their various life experiences related to concepts or phenomena 
(Cresswel, 2014, p. 105). The phenomenological research method is used because it is relevant to this study, which seeks to identify elementary school students' digital literacy skills based on their experience in obtaining and using information from digital media.

Research is conducted in several public or private elementary schools in Indramayu. The research subjects were elementary school students. The flow of phenomenological research according to Stevick, Colaizzi, and Keen (Hasbiansyah, 2008, pp. 171-172) is the determination of the scope of the phenomenon to be studied, the preparation of a list of questions, data collection, data analysis, the essence description stage, and the reporting of research results. As stated by Stevick, Colaizzi, and Keen (Hasbiansyah, 2008, pp. 171-172), the steps of the phenomenological research method analysis consist of the initial stage, the horizontalization stage, and the cluster of the meaning stage.

\section{RESULTS AND DISCUSSION}

\section{Results}

Research findings include: 1) Elementary School Students' Digital Literacy Skills: Acquiring Information through Digital Media; 2) Elementary Students' Digital Literacy Skills: Use of Digital Media; 3) challenges of elementary students in digital literacy; 4) Digitalization of Education 4.0: Learning Achievement through Elementary School Students' Digital Literacy.

\section{a. Primary School Student Digital Literacy Ability}

Regarding the digital literacy of elementary school students, based on the new interviews results, it includes the use of digital literacy as information seeking. There is still a need for a process to train digital literacy from an early age.

The cellphone is only used for legendary mobile games and watching YouTube. Used to learn only when assigned by the teacher. For example, assigned to find information about bones. Then I wrote, just like that. So, if you have a math lesson, I usually look for it on YouTube once. (SC-1)

Search on google if there is a difficult lesson like a math assignment. But sometimes see it on the internet or in textbooks. (CS-2)

Ever done his job on google about learning prime numbers. I have also searched YouTube for prime numbers in mathematics lessons. Only once if you have an assignment. (LD-4) 
School assignments are usually searched on google, not on youtube. I can only find assignment information, though. (PT-5)

Based on the interview above, it can be concluded that the average elementary school student is still limited to searching for information through digital literacy using google and youtube. Also, they are still limited to using digital literacy if assigned to them by the teacher, while digital media such as cellphones are used for games and watching YouTube only.

\section{b. Use of Digital Media}

If you usually see dances like black pink on YouTube, keep looking for decorations to write about hehe. Sometimes search for assignments on google if something is just as difficult as multiplication. (CS-3)

The task of making slime from youtube. It is also seen again when it is just being made. (LD-4)

Based on the interview results, it can be concluded that elementary school students usually use interesting digital literacy such as YouTube with the aim of learning while watching YouTube shows. Youtube is used as a learning medium to make learning easier for elementary students, such as imitating pictures, imitating dances, or imitating mathematical formulas. Meanwhile, google media is used only when students find it difficult to do assignments such as mathematics.

\section{c. Digital Literacy Challenges for Elementary Students}

Often used to play mobile legends, watch youtube channel games. (SC-1)

I often see free fire on YouTube, and the channel mother is mindful of gaming. Sometimes I play TikTok, I see, I don't imitate the styles. (KR-2)

I often see YouTube, play TikTok, and then send whatshap status. (LD-4)

Usually, play legendary mobile games, watch YouTube EXO (PT-5)

Based on the interview above, the challenge faced is the readiness of elementary schoolage students who have not been able to sort out digital media as a learning medium. They still use digital media to find entertainment or games, which results in internet addiction and changes in the students' characteristics. 


\section{d. Achievement of Digital Literacy for Elementary School Students}

From some of the interview results mentioned above. The achievement of the digital literacy of elementary school students is still limited to seeking information. It has not been able to produce a product that can be developed by students. The use of digital media from an early age is still used only for entertainment and games, which results in changes in students' characteristics. Students' addiction to games such as mobile legends, watching YouTube shows, or even playing Tiktok is currently happening.

\section{Discussion}

It is necessary to act together about control of digital media in the industrial era 4.0 by preparing superior human resources and the mental and character readiness of the students themselves so that the achievement of using digital literacy media can function properly in the hope of achieving learning goals. Although the industrial revolution comes with digital developments that provide opportunities for students, on the other hand, some challenges come along with the emergence of these various opportunities. The challenge is that students have not been able to sort wisely, which ones are good or bad, which ones are appropriate to be followed or not, which ones they can access or not, for example, the frequent use of digital media as a vehicle for recreation such as playing games or watching videos (SC-1, KR-2, CM3, LD-4, PT-5). Therefore, students tend to imitate what they get from digital media and the internet. What they imitate can be either positive or negative.

It takes a process to maximize digital literacy in the industrial era 4.0 as a learning medium to improve students' ability to use digital technology. Digital technology in the era of industrial revolution 4.0 has become an important part of modern society. Therefore, it is necessary to collaborate and improve the education system that leads to a new development process in the era of digital technology without forgetting the preparation for students' characterization, which is the most important part of the goals and functions of education. Education should not only develop the potential for thinking (Isfironi, 2015: 331; Koni, 2014: 184; Sujarwo, 2006: 156) but also be directed at shaping attitudes, behavior, and personality (Sujarwo, 2006: 156), including moral development for learners.

Actually, teachers and students can use many digital media in the implementation of learning, such as applications for smartphones that provide videos and e-books or articles for student learning. These applications are available in Indonesian and English, including the 
Guru Room, Udemy, Khan, and Coursera. The content provided varies from learning content in schools to other knowledge, such as general knowledge, language, art, and technology. Although digital technology and the internet are useful when used in learning, its use must be limited and supervised by educators.

\section{CONCLUSION}

Elementary school-age students can already use social media as the use of digital media such as social media such as TikTok, WhatsApp, or YouTube media and have even been frequently used for games such as mobile legends.

Elementary school-age students use digital media or the internet, such as Google, whatshap, and youtube media only used if given an assignment by the teacher. The rest of elementary school students use digital media as a medium for recreational entertainment such as playing games and watching videos.

It takes maturity from various parties to further maximize the development of the use of digital media as a learning medium that can improve student skills and use of information technology in the era of the industrial revolution 4.0 by further improving human resources, facilities, and the role of parents to supervise elementary students in the use of digital media.

Actually, teachers and students can use many digital media in the implementation of learning, such as applications for smartphones that provide videos and e-books or articles for student learning. These applications are available in Indonesian and English, including the Guru Room, Udemy, Khan, and Coursera. The content provided varies from learning content in schools to other knowledge, such as general knowledge, language, art, and technology. Although digital technology and the internet are useful when used in learning, its use must be limited and supervised by educators.

\section{ACKNOWLEDGMENTS}

Anggraeni.H, dkk. (2019). Penguatan Blended Learning Berbasis Literasi Digital Dalam Menghadapi Era Revolusi Industri 4.0. Al-Idarah: Jurnal Kependidikan Islam Volume 9 Nomor 2, 2019. P-ISSN: 2086-6186.http://ejournal.radenintan.ac.id/index.php/idaroh eISSN: 2580-2453.https://doi.org/10.24042/alidarah.v9i2.5168

Ciolacu, M., Tehrani, A. F., Beer, R., \& Popp, H. (n.d.). Education 4.0 - Fostering Student's Performance with Machine Learning Methods. 2017 IEEE 23rd International Symposium for Design and Technology in Electronic Packaging (SIITME). Constanta, Romania. 
Cresswel, J. W. (2014). Penelitian Kualitatif \& Desain Riset: Memilih di Antara Lima Pendekatan. Yogyakarta: Pustaka Pelajar.

Fitri, S. (2017). Dampak Positif dan Negatif Sosial Media Terhadap Perubahan Sosial Anak. Jurnal Naturalistic, Jurnal Kajian Penelitian Pendidikan dan Pembelajaran, Vol.1, No.2, 118-123.

Fitriani.Y dan Aziz.A.I.(2019). Literasi Era Revolusi Industri 4.0. Proseding Seminar Nasional Bahasa dan Sastra. http://research-report.umm.ac.id/index.php/SENASBASA E-ISSN 2599-0519. Halaman 100-104

Hasbiansyah. (2005). Pendekatan Fenomenologi: Pengantar Praktik Penelitian dalam Ilmu Sosial dan Komunikasi. E-Journal UNISBA Terakreditasi Dirjen Dikti SK No. 56/DIKTI/Kep/2005.Tersedia:http://ejournal.unisba.ac.id/indeks.php/mediator/article/vi ewFile/1146714

Herlina.V, dkk. (2019). Pengembangan Buku Cerita Anak Digital Berbasis Literasi Digital pada Siswa Kelas V Sekolah Dasar. Jurnal Dinamika Sekolah Dasar. DOI: doi.org/10.21009/DSD.XXX.

Henniger, Michael L. (2013). Teaching Young Children: An Introduction. United States of America: Pearson Education Inc.

Husni \& Fatulloh. (2016). Kategorisasi Pengguna Internet di Kalangan Pelajar SD dan SMP Menggunakan Metode Twostep Cluster. Proceeding Seminar Nasional Aplikasi Teknologi Informasi (SNATi) 2016, 6-16.

Isfironi, M. (2015). Pentingnya Mereformasi Pendidikan di Indonesia. Jurnal Al—A'adâ Kajian Keislaman dan Kemasyarakatan, Vol. 18, No. 2, 325-334.

Koni, S. (2014). Membangun Sumber Daya Manusia (SDM) Bangsa Melalui Pendidikan Karakter. Jurnal IAIN Gorontalo, Vol. 02, No. 02, 179-186.

Kurniawan, M. R., \& Pambudi, D. I. (2018, October). Literasi Digital dalam Pembelajaran di Sekolah Dasar. In Prosiding Seminar Nasional Pendidikan Dasar 2018. STKIP Bina Bangsa Getsempena.

Moleong, L. J. (2007). Metodologi Penelitian Kualitatif. Bandung: PT Remaja Rosdakarya.

Pratiwi, N., \& Pritanova, N. (2017). Pengaruh literasi digital terhadap psikologis anak dan remaja. Semantik, 6(1), 11-24.

Robandi.B, dkk. (2018). Pedagogik Dalam Era Revolusi Industri 4.0. Jurnal UPSI 2018.

Sujarwo. (2006). Reorientasi Pengembangan Pendidikan di Era Global. Jurnal Dinamika Pendidikan Majalah Ilmu Pendidikan, Vol. XIII, No. 2, 156-168.

Suwandi, S. (2018). Tantangan Mewujudkan Pembelajaran Bahasa Dan Sastra Indonesia Yang Efektif Di Era Revolusi Industri 4.0. Kongres Bahasa Indonesia XI Kemendikbud.

Suwardana, H. (2017). Revolusi Industri 4.0 Berbasis Revolusi Mental. Jati Unik, Vol. 1, No.2, $102-110$ 
Journal of Elementary Education

Volume 5, Number 1, February 2021
P-ISSN: 2580-9326

E-ISSN: 2580-7714

Yahya, M. (2018). Era Industri 4.0: Tantangan dan Peluang Perkembangan Pendidikan Kejuruan Indonesia. Universitas Negeri Makasar, Fakultas Teknik, Makasar. 